\title{
Helicobacter pylori in colorectal neoplasms: is there an aetiological relationship?
}

\author{
Mary Jones ${ }^{1}$, Peter Helliwell ${ }^{1}$, Colin Pritchard ${ }^{2}$, Joseph Tharakan ${ }^{3}$ and \\ Joseph Mathew*1
}

\author{
Address: ${ }^{1}$ Department of Histopathology, Royal Cornwall Hospital, Truro, TR1 3LJ, UK, ${ }^{2}$ Department of Research and Development, Royal \\ Cornwall Hospital, Truro, TR1 3LJ, UK and ${ }^{3}$ Department of Medicine, Princess Alexandra Hospital, Harlow, Essex, UK \\ Email: Mary Jones - mary.jones@rcht.cornwall.nhs.uk; Peter Helliwell - peter.helliwell@rcht.cornwall.nhs.uk; \\ Colin Pritchard - Colin.pritchard@rcht.cornwall.nhs.uk; Joseph Tharakan - tharakan@tinyworld.co.uk; \\ Joseph Mathew* - joe.mathew@rcht.cornwall.nhs.uk \\ * Corresponding author
}

Published: 12 May 2007

World Journal of Surgical Oncology 2007, 5:5। doi:|0.||86/|477-78|9-5-5|

This article is available from: http://www.wjso.com/content/5///5।

(c) 2007 Jones et al; licensee BioMed Central Ltd.

This is an Open Access article distributed under the terms of the Creative Commons Attribution License (http://creativecommons.org/licenses/by/2.0), which permits unrestricted use, distribution, and reproduction in any medium, provided the original work is properly cited.
Received: 12 August 2006

Accepted: 12 May 2007

\begin{abstract}
Background: This pilot study was carried out to determine whether Helicobacter pylori can be detected in normal colon or in association with colorectal neoplasia.

Methods: Paraffin processed colonic tissue blocks of normal colonic mucosa $(n=60)$, and patients diagnosed as adenoma $(n=60)$, and adenocarcinoma $(n=60)$ were retrieved from our archive; the adenoma group included tubular $(n=20)$, tubulovillous $(n=20)$ and villous adenomas $(n=20) .4$ $\mu \mathrm{m}$ sections were stained by immunohistochemical methods using anti-Helicobacter pylori antibodies (polyclonal NCL-HPp and monoclonal NCL-C-jejuni).

Results: Significant numbers of Helicobacter pylori were identified in tubular adenomas (OR = I I. I 3; $95 \% \mathrm{Cl}=1.62-76.70)$, tubulovillous adenomas $(\mathrm{OR}=10.45 ; 95 \% \mathrm{Cl}=1.52-71.52)$ and adenocarcinomas $(\mathrm{OR}=8.13 ; 95 \% \mathrm{Cl}=1.40-46.99)$ compared to controls: there was no association in numbers of Helicobacter pylori and villous adenomas $(\mathrm{OR}=2.95 ; 95 \% \mathrm{Cl}=0.29-9.96)$.

Conclusion: We conclude that although, in this pilot study, there appears to be an association in the prevalence of Helicobacter pylori with some, but not all, colorectal neoplasms, we can not infer causality from these results. These findings need to be further substantiated with a prospective study and the use of molecular biological techniques to determine a causal association.
\end{abstract}

\section{Background}

Colorectal cancers develop sequentially from hyperproliferative epithelium and aberrant crypt foci through to adenocarcinomas, passing through an adenomatous stage $[1,2]$. These adenomatous foci are neoplastic intraluminal protuberant, occasionally flat, dysplastic glandular lesions, represented by tubular or villous adenomas at either architectural extreme [3]; aetiologically, environ- mental, social and genetic factors or influences have been implicated in their genesis [4-7]. The possibility however of Helicobacter pylori (HP) as an initiator of colorectal neoplasia $[8,9]$, similar to its role in gastric carcinoma and lymphoma $[3,10]$ is subject of investigation. It is well established that HP is associated with extragastric disease [11], as are several non-HP species [12,13]; indeed HP has been identified outwith the stomach $[11,14-16]$, in the 
intestine $[14,15,17]$ as well as in faeces [18]. Most associations between neoplastic colorectal lesions (adenomas and carcinomas) and HP are based on studies correlating these lesions with HP seropositivity [9,19-23] or, indirect evidence such as increased gastrin $[24,25]$ or CagA+ levels [24]. Other studies have failed to demonstrate this association based on seropositivity [26-28]; indeed it has been suggested that HP does not colonise rectal mucosa [29].

In this study we have used immunohistochemical methods to interrogate normal, adenomatous colorectal tissue and colorectal adenocarcinomas for the presence of HP, using anti-HP antibodies.

\section{Methods}

This pilot study was independently examined and ethically approved by the Local Research Ethics Committee, Royal Cornwall Hospital, Cornwall, UK.

Samples of paraffin-embedded colorectal tissue $(n=180)$ including normal $(n=60)$, adenomas $(n=60)$ and adenocarcinomas $(n=60)$ were retrieved from departmental archives. Sixty samples of each diagnosis gave an acceptable precision for the prevalence estimates. This powered the study at $0.80(\alpha=0.05)$ to detect an absolute difference of $26 \%$ in the prevalence of the different diagnoses. Specimens were not matched for age, sex or socioeconomic status as it was thought that this would confound any comparisons; a higher prevalence in adenocarcinomas might simply reflect the greater age of the people with this type of neoplasia. However, the age and sex were adjusted for using binary logistic regression once the results had been established. The number of males and females and their mean ages in each group is shown in Table 1. Patients included in the normal category had biopsies for non-specific gastrointestinal symptoms, iron deficiency investigation or diarrhoea, but whose histology was unremarkable.

Each sample group of patients was separate and mutually exclusive. Patients with normal biopsies did not have a biopsy history of colorectal adenomas or carcinomas, or other carcinoma. The patient group with adenomas did not have a biopsy history of colorectal or other carcinoma. Patients with colorectal adenocarcinoma formed the third group: these patients did not have a biopsy history of cancer at any other site. The limitations of this study include unavailability of information relating to serology or breath test or, preceding gastric biopsy.

Since there is a sequential progression of colorectal polyps to colorectal adenocarcinoma, 20 cases each of tubular, tubulovillous and villous adenomas were selected. Immunohistochemical techniques were chosen because they are more specific and sensitive than tinctorial techniques [3033].

Cases were identified from the histopathology database between 1996 and 2001, using appropriate T and M codes and the relevant paraffin blocks were retrieved. Topographical code $\mathrm{T} 67^{*} / 68^{*}$ identified biopsies from the colorectum. Morphology code M00100 identified biopsies considered normal; M80400, M82630, M82611 and M81403 detected adenomas and carcinomas.

Four $4 \mu \mathrm{m}$ sections were cut from each of the 180 formalin fixed paraffin blocks using a Leica ${ }^{\circledast}$ rotary microtome. Diagnosis were confirmed with an H/E stain; the other sections were used for immunohistochemistry. H/E and immunohistochemistry were used to detect HP organisms; Giemsa was not used. The immunohistochemically stained slides were randomized, given individual research numbers and then examined by light microscopy

Two Novocastra ${ }^{\circledR}$ antibodies were used: 1) polyclonal NCL-HPp (specific and sensitive for HP; dilution 1:150)[34,35] and, 2) monoclonal NCL-C-jejuni (raised against campylobacter jejuni; dilution 1:800), which crossreacts with HP. The use of two antibodies allowed for identification and differentiation of HP from Campylobacter in our study material. The strategy was to see whether we could identify one or the other, using immunohistochemistry on protocol samples.

Antigen retrieval was carried out in a citrate buffer pH6.0 for 30 minutes at $430 \mathrm{~W}$ in a domestic microwave. This method was chosen over the Novocastra recommended trypsin digestion following experiments comparing both methods, as recommended[34,35]. Positive controls were gastric biopsies known to be positive for HP; the primary antibody was omitted in negative controls.

The detection method followed was that provided by Dako with the ChemMate ${ }^{\mathrm{TM}}$ Envision detection kit [36]. The ChemMate ${ }^{\mathrm{TM}}$ Envision detection kit was used as the dextran polymer based secondary antibody technique is a two step process which is fast, reliable and with superior sensitivity to the avidin-biotin method [36].

Sections were counterstained using Mayer's Haematoxylin for 1 minute and blued in Scotts Tap water. Odds ratios (OR) were estimated using the Logit procedure in SPSS11.

\section{Results}

Four cases were excluded from this analysis; two from the normal tissue group, one from the adenocarcinoma group and one from the tubular adenoma group. These were due to inadequate tissue samples. 
Table I: Histological prevalence of HP and demographics of patients with colorectal neoplasms and controls

\begin{tabular}{|c|c|c|c|c|c|}
\hline \multirow[t]{2}{*}{ Pathology diagnosis } & \multirow[t]{2}{*}{ Adenocarcinoma } & \multicolumn{3}{|l|}{ Adenoma } & \multirow[t]{2}{*}{ Normal (Controls) } \\
\hline & & Villous & Tubulovillous & Tubular & \\
\hline Number of cases & 59 & 20 & 20 & 19 & 58 \\
\hline Male:Female & $22: 37$ & $9: 11$ & $13: 7$ & $14: 6$ & $25: 33$ \\
\hline Mean age (range) & $67.55(36-9 I)$ & $73.85(55-94)$ & $69.45(47-84)$ & $66.75(44-84)$ & $51.60(22-86)$ \\
\hline HP prevalence (\%positive) & $10 / 5916.9$ & $1 / 205$ & $4 / 2020$ & $4 / 1921$ & $1 / 58 \quad 1.7$ \\
\hline Odds ratio (OR) $(95 \% \mathrm{Cl})$ & $8.13(1.40-46.99)$ & $2.95(0.29-9.96)$ & $10.45(1.52-71.52)$ & $11.13(1.62-76.70)$ & \\
\hline Age-sex adjusted Odds Ratio $(95 \% \mathrm{Cl})$ & $8.73(1.01-75.48)$ & $1.94(0.10-36.77)$ & $5.73(1.02-1 / 2.83)$ & $11.53(1.12-118.98)$ & \\
\hline
\end{tabular}

HP organisms were golden-brown "dot-like" and granular against a light blue Haematoxylin counterstain. We were unable to unequivocally detect the spiral form of HP on $\mathrm{H} / \mathrm{E}$ or immunohistochemistry in any of our normal or neoplastic colonic biopsy samples; we assume from this that the "granular" HP-positive organisms represented the coccoid form [37-39] of the organism. Figure 1 shows positive anti-HP immunohistochemical reactions in control gastric mucosa with NCL-HPp (Figure 1a \&1b). Figure 2 shows colonic mucosa with positive anti-NCL-HPp (Figure 2a) and anti-NCL-C-jejuni (Figure 2b) immunohistochemistry. The positivity with both antibodies was convergent; we did not observe positivity of one antibody without the other also being positive. We concluded from this that we were observing only HP organisms, rather than non-HP organisms or other Helicobacter species. These organisms were luminal[32,40] although a rare organism was seen in a crypt. Their staining patterns were similar to that in the stomach although in the latter, organisms were frequently seen in glandular lumina.

The patient demographics and results are listed in table 1. There were more females in each group, with the exception of patients with tubular and tubulovillous adenomas. HP was detected in only one normal (control) (2\%) specimen but between 17 and $21 \%$ of patients with colorectal neoplasia; only $5 \%$ of patients with villous adenomas showed immunoreactivity for HP organisms. Compared to normal (controls) therefore, significant numbers of HP are seen in tubular (OR 11.13; 95\% Confidence interval (CI) 1.62-76.60) and tubulo-villous (OR 10.45; 95\% CI 1.52-71.52) adenomas and, in adenocarcinoma (OR $8.13 ; 95 \%$ CI 1.40-46.99) but not in villous adenomas (OR 2.95; 95\% CI 0.29-9.96).

\section{Discussion}

We have used immunohistochemical methods to demonstrate that HP organisms do reside in the colorectum associated with colorectal neoplasms. Although we can not attribute a cause-and-effect relationship in this instance, there is certainly indirect evidence demonstrating this association $[9,19-25,41,42]$, as there is evidence refuting it [26-29]. Clearly, the use of serum-based methods can lead to ambiguous results especially since antibodies can be detectable a long time after the bacteria have ceased to colonise the gut[28].

We used immunohistochemical detection methods rather than routine histochemistry (Giemsa) as the former are said to be more accurate[32] and are more likely to detect non-spiral forms of the organism[31,33,37-39]. However Giemsa has been reported to be more sensitive for the detection of spiral gastric forms of the organism[43].

Our results show that the prevalence of HP is significant in tubular and tubulovillous adenomas but not in villous adenomas; the reason for this is unclear. It may be that the microenvironment in villous adenomas does not support $\mathrm{HP}$ in a similar manner to absence of HP in foci of intestinal metaplasia in the stomach[5] or, low HP prevalence is some types of gastric fundic polyps[44]. The absence of HP in association with villous adenomas does not necessarily signify an absence of an association but merely that HP could have migrated away from these polyps after having initiated the lesion (if indeed there is such a relationship). This would be analogous to HP migration having first produced gastric abnormalities[45].

Although some studies have not been able to substantiate an association between HP and colorectal neoplasia and HP [26-28] or, that these organisms can colonise the colon $[29,46]$, we have been able to demonstrate their presence (using immunohistochemistry) in certain types of colorectal neoplasia; we have not looked at HP in association with other non-neoplastic epithelial lesions. Indeed, in one study, $27 \%$ of colorectal adenocarcinomas contained Helicobacter DNA; however, this study could not determine a statistical association between its presence and the different Dukes stages of colorectal adenocarcinomas or, between colonic and rectal adenocarcinomas[41].

HP-induced carcinogenesis is thought to be initiated by gastrin-induced genomic instability (gastrin hypersecretion being promoted by the antral effects of HP), its vacuolating toxin VacA [47-50], and upregulation of COX$2[24,51]$. Most of these studies have been able to define this relationship based on serological data but does not 

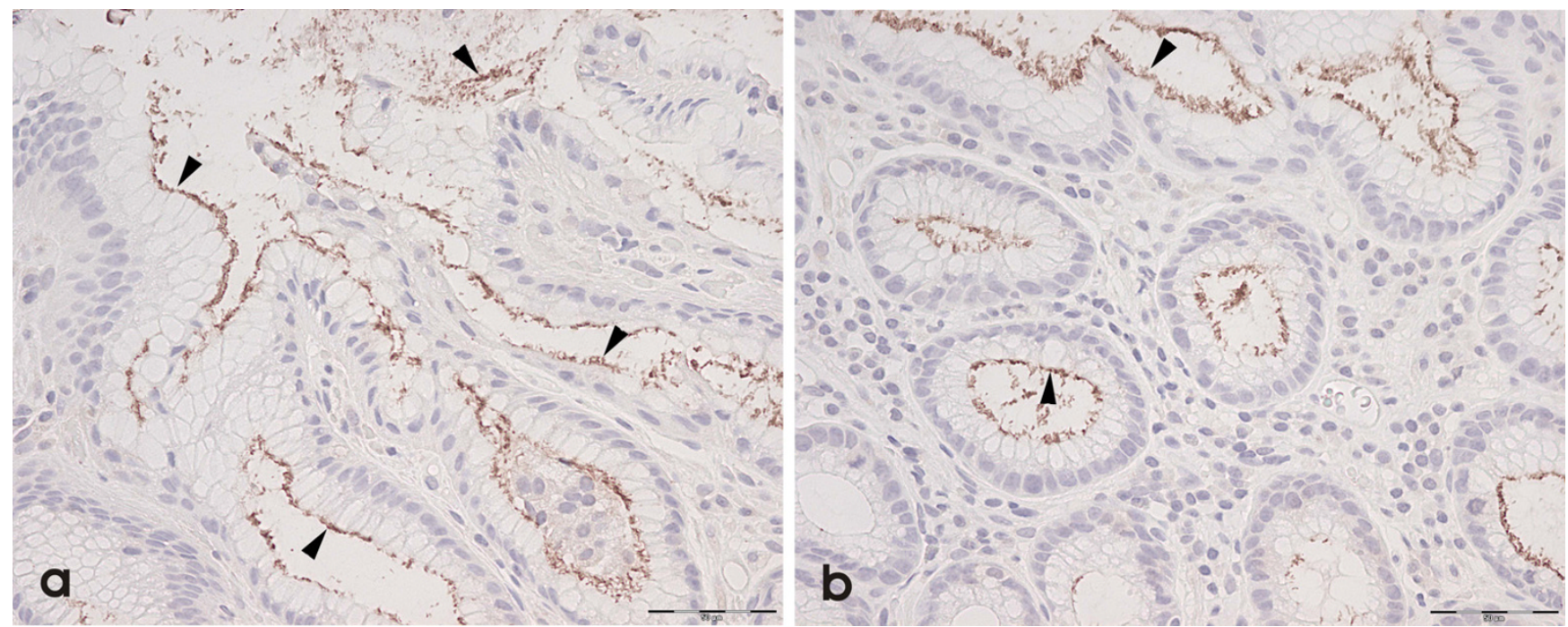

Figure I

Positive HP immunohistochemistry (arrowheads) is seen in gastric control material using NCL-HPp (a \& b) (internal scale $=50$ $\mu \mathrm{m})$.

address direct colonisation of colorectal mucosa as a necessary ingredient in the evolution of colorectal neoplasia; indeed these theories define remote activation of colorectal neoplasia by upstream HP activity and effects. Could, for instance, in some circumstances, remote and local effects synergise to initiate or produce these neoplasms $[42,52]$ ?

Experimentally, 129/SvEv Rag-2-deficient mice have been shown to develop colitis and colonic cancer in the pres- ence of Helicobacter. hepaticus[53], with implications relating to immune regulation in this process. More recently, colonic adenocarcinomas have been initiated in SMAD3deficient mice that have been exposed to Helicobacter infection suggesting a causal association[42].

Whereas we acknowledge that the presence of HP in our study does not necessarily mean that local HP effects are responsible for colorectal neoplasia, but neither does it exclude it. It is entirely possible also that these HP organ-
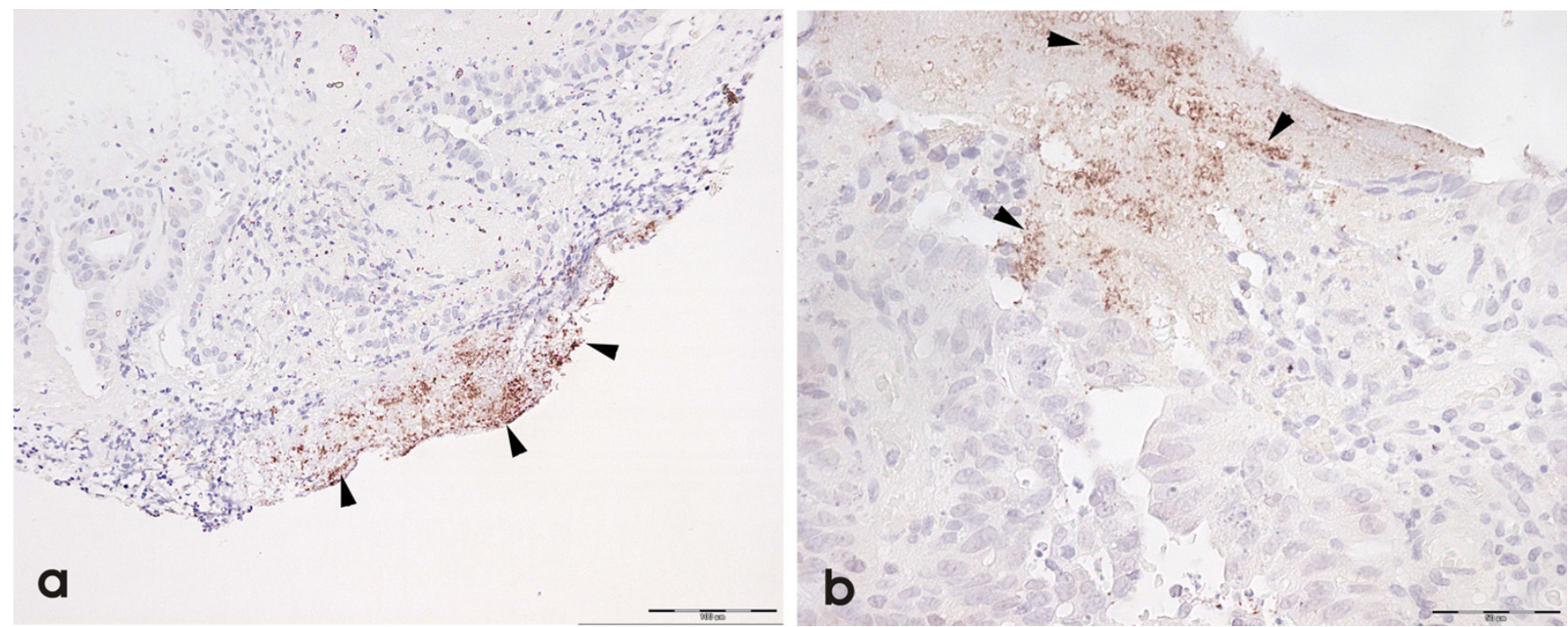

Figure 2

Immunopositivity is seen in colorectal neoplasia using a) NCL-HPp and b) NCL-C-Jejuni (internal scale $=50 \mu \mathrm{m}$ ). 
isms are transiting the bowel and their localisation in colorectal neoplasia, fortuitous. We have also considered the possibility these results could reflect identification of HP or HP-like antigens in luminal debris: whist we can not exclude this, our anti-HP antibody is HP-specific [54]. Clearly this pilot study needs to be progressed to molecular biological techniques such as the polymerase chain reaction (PCR); PCR however is said to be no more sensitive than routine histopathological or microbiological techniques[32]; these methods require stringency in the collection of diagnostic material[32].

\section{Conclusion}

We have been able to identify HP organisms in colorectal neoplasms using immunohistochemical methods in this pilot study. We have also been able to demonstrate an association in their presence with tubulovillous and tubulovillous adenomas and adenocarcinomas, but not with villous adenomas. These findings need to be further substantiated with a prospective study and the use of molecular biological techniques to determine a causal association.

\section{Competing interests}

The author(s) declare that they have no competing interests.

\section{Authors' contributions}

This manuscript is the essence of the MSc Thesis of MJ. The idea for this research was developed by JT, JM, PH and MJ with CP providing the statistical validities before, during and after the study. All slides were reviewed by MJ, PH and JM before and after immunohistochemistry. The immunohistochemistry was optimised by MJ. Randomisation of cases was done by a colleague. The authors have been variously but actively involved in its conception and design, analysis and interpretation of data, in the preparation and critical evaluation of its content, have read and approved the final manuscript.

\section{Financial support}

We acknowledge contributions from the following sources

1. Cellular Pathology Research Funds (JM is a co-signatory)

\section{Sunrise Appeal}

\section{Silverfern Research.}

\section{Acknowledgements}

We acknowledge the assistance of Mr Anthony Gledhill during the experimental phase of this study.

\section{References}

I. Cummings OW: Pathology of the adenoma-carcinoma sequence: from aberrant crypt focus to invasive carcinoma. Semin Gastrointest Dis 2000, I I :229-237.

2. Hardy RG, Meltzer SJ, Jankowski JA: ABC of colorectal cancer: Molecular basis for risk factors. BMJ 2000, $32 \mathrm{I}: 886-889$.

3. Day DW, Jass JR, Price AB, Shepherd NA, Sloan JM, Talbot IC, Warren BF, Williams GT: Morson and Dawson's gastrointestinal pathology. 4th edition. Oxford, Blackwell Science Ltd; 2003.

4. Gryfe R, Swallow C, Bapat B, Redston M, Gallinger S, Couture J: Molecular biology of colorectal cancer. Curr Probl Cancer 1997, 2 I :233-300.

5. Liu C, Crawford JM: The gastrointestinal tract. In Robbins and Cotran Pathologic Basis of Disease 7th edition. Edited by: Kumar V, Abbas AK and Fausto N. Philadelphia, Elsevier Saunders; 2005:797-875.

6. Midgley R, Kerr D: Colorectal cancer. Lancet 1999, 353:391-399.

7. Vogelstein B, Fearon ER, Hamilton SR, Kern SE, Preisinger AC, Leppert M, Nakamura Y, White R, Smits AM, Bos JL: Genetic alterations during colorectal-tumor development. $N$ Engl J Med 1988, 3 19:525-532.

8. Konturek SJ, Konturek PC, Hartwich A, Hahn EG: Helicobacter pylori infection and gastrin and cyclooxygenase expression in gastric and colorectal malignancies. Regul Pept 2000, 93: I3-19.

9. Meucci G, Tatarella M, Vecchi M, Ranzi ML, Biguzzi E, Beccari G, Clerici E, de Franchis R: High prevalence of Helicobacter pylori infection in patients with colonic adenomas and carcinomas. J Clin Gastroenterol 1997, 25:605-607.

10. Calam J: Clinician's guide to Helicobacter pylori. , Chapman and Hall, London; 1996.

II. Konturek SJ, Konturek PC, Pieniazek P, Bielanski W: Role of Helicobacter pylori infection in extragastroduodenal disorders: introductory remarks. J Physiol Pharmacol 1999, 50:683-694.

12. Fox JG: The non-H pylori helicobacters: their expanding role in gastrointestinal and systemic diseases. Gut 2002, 50:273-283.

13. O'Rourke JL, Grehan M, Lee A: Non-pylori Helicobacter species in humans. Gut 200I, 49:601-606.

14. de Cothi GA, Newbold KM, O'Connor HJ: Campylobacter-like organisms and heterotopic gastric mucosa in Meckel's diverticula. J Clin Pathol 1989, 42: I32-134.

15. Dye KR, Marshall BJ, Frierson HF Jr., Pambianco DJ, McCallum RW: Campylobacter pylori colonizing heterotopic gastric tissue in the rectum. Am J Clin Pathol 1990, 93: I44-I 47.

16. McNamara D, O'Morain C: Gastro-oesophageal reflux disease and Helicobacter pylori: an intricate relation. Gut 1999, 45 Suppl I:II3-7.

17. Croucher SC, Houston AP, Bayliss CE, Turner RJ: Bacterial populations associated with different regions of the human colon wall. Appl Environ Microbiol 1983, 45: I025-1033.

18. Thomas JE, Gibson GR, Darboe MK, Dale A, Weaver LT: Isolation of Helicobacter pylori from human faeces. Lancet 1992, 340: I 194-I I95.

19. Aydin A, Karasu Z, Zeytinoglu A, Kumanlioglu K, Ozacar T: Colorectal adenomatous polyps and Helicobacter pylori infection. Am J Gastroenterol 1999, 94: I I 2 I- I I 22.

20. Breuer-Katschinski B, Nemes K, Marr A, Rump B, Leiendecker B, Breuer N, Goebell $\mathrm{H}$ : Helicobacter pylori and the risk of colonic adenomas. Colorectal Adenoma Study Group. Digestion 1999, 60:210-215.

21. Fireman Z, Trost L, Kopelman Y, Segal A, Sternberg A: Helicobacter pylori: seroprevalence and colorectal cancer. Isr Med Assoc J 2000, 2:6-9.

22. Fujimori S, Kishida T, Kobayashi T, Sekita Y, Seo T, Nagata K, Tatsuguchi A, Gudis K, Yokoi K, Tanaka N, Yamashita K, Tajiri T, Ohaki Y, Sakamoto C: Helicobacter pylori infection increases the risk of colorectal adenoma and adenocarcinoma, especially in women. J Gastroenterol 2005, 40:887-893.

23. Mizuno S, Morita $Y$, Inui T, Asakawa A, Ueno N, Ando T, Kato $H$, Uchida M, Yoshikawa T, Inui A: Helicobacter pylori infection is associated with colon adenomatous polyps detected by highresolution colonoscopy. Int J Cancer 2005.

24. Hartwich J, Konturek SJ, Pierzchalski P, Zuchowicz M, Konturek PC, Bielanski W, Marlicz K, Starzynska T, Lawniczak M: Molecular basis of colorectal cancer - role of gastrin and cyclooxygenase-2. Med Sci Monit 2001, 7:II7I-II8I. 
25. Konturek PC, Bielanski W, Konturek SJ, Hartwich A, Pierzchalski P, Gonciarz M, Marlicz K, Starzynska T, Zuchowicz M, Darasz Z, Gotze JP, Rehfeld JF, Hahn EG: Progastrin and cyclooxygenase-2 in colorectal cancer. Dig Dis Sci 2002, 47: 1984-1991.

26. Limburg PJ, Stolzenberg-Solomon RZ, Colbert LH, Perez-Perez GI, Blaser MJ, Taylor PR, Virtamo J, Albanes D: Helicobacter pylori seropositivity and colorectal cancer risk: a prospective study of male smokers. Cancer Epidemiol Biomarkers Prev 2002, I I:1095-1099.

27. Moss SF, Neugut AI, Garbowski GC, Wang S, Treat MR, Forde KA: Helicobacter pylori seroprevalence and colorectal neoplasia: evidence against an association. I Natl Cancer Inst 1995, 87:762-763.

28. Siddheshwar RK, Muhammad KB, Gray JC, Kelly SB: Seroprevalence of Helicobacter pylori in patients with colorectal polyps and colorectal carcinoma. Am J Gastroenterol 200I, 96:84-88.

29. Luzza F, Maletta M, Imeneo M, Monteleone G, Marasco R, Biancone $\mathrm{L}$, Pallone F: Evidence against colonic mucosa colonisation by Helicobacter pylori. Lack of a specific antibody response in homogenates of rectal endoscopic biopsies. Ital J Gastroenterol 1996, 28:447-45।.

30. Rotimi O, Cairns A, Gray S, Moayyedi P, Dixon MF: Histological identification of Helicobacter pylori: comparison of staining methods. J Clin Pathol 2000, 53:756-759.

31. Marzio L, Angelucci D, Grossi L, Diodoro MG, Di Campli E, Cellini L: Anti-Helicobacter pylori specific antibody immunohistochemistry improves the diagnostic accuracy of Helicobacter pylori in biopsy specimen from patients treated with triple therapy. Am / Gastroenterol 1998, 93:223-226.

32. McNulty CA, Wyatt JI: ACP. Best practice no 154. February 1999. Helicobacter pylori. J Clin Pathol I999, 52:338-344.

33. Saito N, Sato F, Kato M, Takeda H, Sugiyama T, Asaka M, paper : What does the positivity of a monoclonal antibody against $\mathbf{H}$ pylori mean? Helicobacter 1998, 3:143.

34. Ashton-Key M, Diss TC, Isaacson PG: Detection of Helicobacter pylori in gastric biopsy and resection specimens. J Clin Pathol |996, 49: |07-III.

35. Maclntyre N: Unmasking antigens for immunohistochemistry. $\mathrm{Br} J$ Biomed Sci 2001, 58:190-196.

36. Sabattini E, Bisgaard K, Ascani S, Poggi S, Piccioli M, Ceccarelli C, Pieri F, Graternali-Orcioni G, Pileri SA: The EnvisionTM+ system: a new immunohistochemical method for diagnostic research. Critical comparison with the APAAP,ChemMateTM, CSA,LABC, and SABC techniques. Journal of Clinical Pathology |998, 5 I:506-5I I.

37. Chan WY, Hui PK, Leung KM, Chow J, Kwok F, Ng CS: Coccoid forms of Helicobacter pylori in the human stomach. Am J Clin Pathol 1994, 102:503-507.

38. Chaput C, Ecobichon C, Cayet N, Girardin SE, Werts C, Guadagnini $S$, Prevost MC, Mengin-Lecreulx D, Labigne A, Boneca IG: Role of AmiA in the Morphological Transition of Helicobacter pylori and in Immune Escape. PLoS Pathog 2006, 2:.

39. Saito N, Oda H, Sato F, Kato M, Takeda H, Sugiyama T, Asaka M: Ultrastructure of helicobacter pylori. Journal of Gastroenterology and Hepatology 2000, I 5: $\mathrm{H} 25-\mathrm{H} 25$.

40. Saito N, Sato F, Oda H, Kato M, Takeda H, Sugiyama T, Asaka M, paper : Removal of mucus for ultrastructural observation of the surface of human gastric epithelium using pronase. Helicobacter 2002, 7:112-115.

4I. Grahn N, Hmani-Aifa M, Fransen K, Soderkvist P, Monstein HJ: Molecular identification of Helicobacter DNA present in human colorectal adenocarcinomas by I6S rDNA PCR amplification and pyrosequencing analysis. J Med Microbiol 2005, 54:1031-1035

42. Maggio-Price L, Treuting $P$, Zeng W, Tsang M, Bielefeldt-Ohmann H, Iritani BM: Helicobacter infection is required for inflammation and colon cancer in SMAD3-deficient mice. Cancer Res 2006, 66:828-838.

43. Vorobjova T, Maaroos HI, Rago T, Zimmermann A, Uibo R: Helicobacter pylori $(H$. pylori) in gastric mucosa of children with abdominal complaints: immunohistochemistry detects antigen-reactive corpus mucosa cells. Helicobacter 1998, 3: 103-109.

44. Shand AG, Taylor AC, Banerjee M: Gastric fundic polyps in South East Scotland: absence of adenomatous polyposis gene mutations and a strikingly low prevalence of HP infection. Journal of Gastroenterology and Hepatology 2002, I 7: I I 6 I-I I 64.
45. Jung $A$, Vieth $M$, Maier $O$, Stolte $M$ : Fundic gland polyps of the gastric mucosa. A marker for colorectal epithelial neoplasia. Pathology Research Practical 2002, I 98:731-734.

46. Bell SJ, Chisholm SA, Owen RJ, Borriello SP, Kamm MA: Evaluation of Helicobacter species in inflammatory bowel disease. Aliment Pharmacol Ther 2003, I 8:48I-486.

47. Luzzi I, Pezzella C, Caprioli A, Covacci A, Bugnoli M, Censini S: Detection of vacuolating toxin of Helicobacter pylori in human faeces. Lancet I993, 34 I: 1348

48. Russo F, Notarnicola M, Di Matteo G, Leoci C, Caruso ML, Pirrelli M, Caradonna M, Morandi L, Di Leo A: Detection of Helicobacter pylori cagA gene by polymerase chain reaction in faecal samples. Eur J Gastroenterol Hepatol I999, I I:25 I-256.

49. Shmuely H, Passaro D, Figer A, Niv Y, Pitlik S, Samra Z, Koren R, Yahav J: Relationship between Helicobacter pylori CagA status and colorectal cancer. Am J Gastroenterol 200I, 96:3406-34 I0.

50. Kabir S: Detection of Helicobacter pylori DNA in feces and saliva by polymerase chain reaction: a review. Helicobacter 2004, 9:11 5-123.

5I. Hartwich A, Konturek SJ, Pierzchalski P, Zuchowicz M, Labza H, Konturek PC, Karczewska E, Bielanski W, Marlicz K, Starzynska T, Lawniczak $M$, Hahn EG: Helicobacter pylori infection, gastrin, cyclooxygenase-2, and apoptosis in colorectal cancer. Int Colorectal Dis 2001, 16:202-210.

52. Rao VP, Poutahidis T, Ge Z, Nambiar PR, Boussahmain C, Wang YY, Horwitz BH, Fox JG, Erdman SE: Innate immune inflammatory response against enteric bacteria Helicobacter hepaticus induces mammary adenocarcinoma in mice. Cancer Res 2006, 66:7395-7400.

53. Erdman SE, Poutahidis T, Tomczak M, Rogers AB, Cormier K, Plank B, Horwitz BH, Fox JG: CD4+ CD25+ Regulatory T Lymphocytes Inhibit Microbially Induced Colon Cancer in Rag2Deficient Mice. Am J Pathol 2003, 162:691-702.

54. Novocastra Laboratories: Data Sheet. Helicobacter pylori, rabbit polyclonal antibody. NCL-HPp. [http://www.novocas tra.co.uk/ce/usa/origin/ORG-8994.pdf].

Publish with Bio Med Central and every scientist can read your work free of charge

"BioMed Central will be the most significant development for disseminating the results of biomedical research in our lifetime. "

Sir Paul Nurse, Cancer Research UK

Your research papers will be:

- available free of charge to the entire biomedical community

- peer reviewed and published immediately upon acceptance

- cited in PubMed and archived on PubMed Central

- yours - you keep the copyright
BioMedcentral 